\title{
Siirt İlinde Yüksek Hepatit Delta Antikoru Sıklığı
}

\author{
Tayibe BAL ${ }^{1}$
}

\section{Öz}

Amaç: Eş zamanlı hepatit delta virüs (HDV) enfeksiyonu varlığı kronik hepatit B (KHB) ilişkili karaciğer hastalığının seyrini olumsuz yönde etkilemektedir. Bu çalışmada Siirt ilinde hepatit B virusu (HBV) ile kronik olarak enfekte olan hepatit gelişmiş ve gelişmemiş olgularda delta antikoru (anti-HDV) sıklığının belirlenmesi ve HDV koenfeksiyonu varlığının klinik etkilerinin irdelenmesi amaçlanmıştır.

Gereç ve Yöntemler: Bu retrospektif kesitsel çalışmaya Şubat 2017-Şubat 2018 tarihleri arasında Siirt Devlet Hastanesi Enfeksiyon Hastalıkları polikliniğine başvuran Anti-HDV testi bakılmış 288'i HBV ile kronik olarak enfekte, 174'ü KHB gelişmiş toplam 462 olgu dahil edildi. HBV deoksiribonükleik asit (DNA), hepatit B "e" antijeni ( $\mathrm{HBe} \mathrm{Ag}$ ), alanin aminotransferaz (ALT), HDV ribonükleik asit (RNA) sonuçları ile siroz ve hepatosellüler karsinom (HCC) durumu ile ilgili verilere retrospektif olarak ulaşılmıştır. Çalışmaya alınan hastalar Anti-HDV pozitif ( $\mathrm{n}=128)$ ve negatif $(\mathrm{n}=334)$ olmak üzere iki gruba ayrıldı. KHB, siroz ve HCC sıklı̆̆ı gruplar arasında karşılaştırılmış̧ır.

Bulgular: Toplam 462 olgunun 205’i (\%44,4) kadın, 257'si erkek (\%55,6) olup, medyan yaşı 37 (çeyrekler arası aralık (IQR) 26 ila 49) idi. Anti-HDV pozitifliği saptanan toplam 128 (\%27,8) olgunun 32'sinde HDV RNA çalışılabilmiş ve 9 'unda pozitif olarak saptanmıştır. Çalışmamızda nonsirotik ve sirotik olgulardaki anti-HDV sıklığının sırasıyla \%26,2 ve $\% 68,8$ olduğu görülmüștür. Anti-HDV pozitif olgularda KHB, siroz ve HCC sıklığının Anti-HDV negatif olgulara göre anlamlı oranda yüksek olduğu görülmüştür $(\mathrm{p}=0,003, \mathrm{p}=0,001, \mathrm{p}=0,021)$.

Sonuç: Bu çalışmada elde edilen verilere dayanarak, Siirt ilinde HBV ile enfekte olgularda Anti-HDV sıklığının Türkiye ortalamasının $(\% 5,2)$ çok üzerinde olduğu ve Anti-HDV pozitif olguların KHB, siroz ve HCC gelişimi açısından Anti-HDV negatif olgulara oranla daha yakın izlem gerektirdiği söylenebilir.

Anahtar Kelimeler: Hepatit delta virüs; hepatosellüler karsinom; kronik hepatit B; siroz.

\section{High Prevalence of Hepatitis Delta Antibody in Siirt Province}

\begin{abstract}
Aim: The presence of concomitant hepatitis delta virus (HDV) infection negatively affects the course of chronic hepatitis B (CHB) related liver disease. In this study, it was aimed to determine the frequency of delta antibody (antiHDV) and to investigate the clinical effects of hepatitis delta virus (HDV) coinfection in patients with CHB and who are chronically infected with hepatitis B virus (HBV) in Siirt.

Material and Methods: In this retrospective cross-sectional study, a total of 462 cases, 288 of whom were chronically infected with HBV and 174 with CHB, who were admitted to the Siirt State Hospital Infectious Diseases outpatient clinic between February 2017 and February 2018, were included. Data on HBV deoxyribonucleic acid (DNA), hepatitis "e" antigen (HBeAg), alanine aminotransferase (ALT), HDV ribonucleic acid (RNA) results and cirrhosis and hepatocellular carcinoma (HCC) status were accessed retrospectively. The patients included in the study were divided into two groups as anti-HDV positive $(n=128)$ and negative $(n=334)$. The frequency of $\mathrm{CHB}$, cirrhosis and HCC were compared between the groups.
\end{abstract}

Results: Of the 462 cases in total, 205 (44.4\%) were female and 257 (55.6\%) were male and the median age was

\footnotetext{
1 Mustafa Kemal Üniversitesi, Enfeksiyon Hastalıkları ve Klinik Mikrobiyoloji Kliniği, Hatay, Türkiye
} 
37 (interquartile range (IQR): 26 to 49). Anti-HDV was positive in $128(27.8 \%)$ of these cases, only 32 cases were examined for HDV RNA and 9 were positive. In our study, the frequency of anti-HDV in non-cirrhotic and cirrhotic cases was found to be $26.2 \%$ and $68.8 \%$, respectively. It was observed that the frequency of $\mathrm{CHB}$, cirrhosis and HCC were significantly higher in anti-HDV positive cases compared to anti-HDV negative cases ( $\mathrm{p}=0.003, \mathrm{p}=0.001, \mathrm{p}=0.021$ ).

Conclusion: Based on the data obtained from the present study, we consider that, in Siirt province, the prevalence of anti-HDV in the patients infected with HBV is much higher than average for Turkey. Additionally, it can be said that anti-HDV positive cases require closer monitoring compared to anti-HDV negative cases in terms of CHB, cirrhosis and HCC development.

Keywords: Hepatitis delta virus; chronic hepatitis B; cirrhosis; hepatocellular carcinoma.

\section{GIRIS}

Hepatit delta virüsü (HDV), replikasyonu ve transmisyonu için hepatit $B$ virüs (HBV) varlığına gereksinim duyan defektif bir virüstür (1). Dünya genelinde yaklaşık 468 milyon kişinin HBV ile enfekte olduğu ve bunun \%10,58'i (yaklaşık 49,5 milyon) kadarının HDV ile koenfekte olgulardan oluşturduğu tahmin edilmektedir (2,3). Dünyadaki HDV enfeksiyonu prevalansı HBV enfeksiyonuna oranla düşük olsada HDV seroprevalansının tahmin edilenden daha yüksek olabileceği ile ilgili veriler artmaktadır $(4,5)$.

Bunun yanında HBV ile eş zamanlı HDV enfeksiyonu en ciddi seyirli kronik viral hepatit formu olarak kabul edilmekte olup HBV monoenfeksiyonuna oranla daha hızlı siroza gidiş ve daha yüksek hepatosellüler karsinom (HCC) riski ile ilişkili olduğu bildirilmiştir $(6,7)$. HDV enfeksiyonunun sirotik olgularda ve HCC olgularında daha yüksek oranlarda görülüyor olması da HDV enfeksiyonunun agresif klinik gidişinin bir diğer kanıtıdır (4). Öte yandan HBV ve hepatit C virusu (HCV) enfeksiyonunun aksine HDV için geliştirilmiş etkili bir antiviral tedavinin bulunmaması karaciğer ilişkili mortalite ve morbiditede HDV enfeksiyonunun payını arttırmaktadir $(4,8)$. Bu nedenle yakın gelecekte HDV enfeksiyonu ile ilgili klinik çalışmaların süreceği hatta ivme kazanabileceği söylenebilir.

HDV Endemik bölgelerin belirlenmesi uygun kontrol önlemlerinin alınabilmesinde önemli bir basamaktır. Öte yandan bölgesel epidemiyolojik verilerin güncellenmesi bölgedeki HDV ilişkili mortalite ile morbiditenin azaltılmasında fayda sağlamasının yanısıra global eradikasyon planına da katkı sağlayacaktır. Türkiye genelinde HDV prevalansı \%2,8 iken bu oran bölgeden bölgeye değişebilmekte, Güneydoğu ve Doğu Anadolu Bölgeleri'nde \%46,3'lere ulaşabilmektedir (9). Siirt ili ülkemizin Güneydoğu Anadolu Bölgesi'nde yer almasına rağmen mevcut literatürde Siirt'te kronik hepatit B (KHB) olgularındaki delta antikoru sıklığını ve klinik etkilerini inceleyen çalışma bulunmamaktadır.

Bu çalışmada Siirt ilinde HBV ile kronik olarak enfekte olan hepatit gelişmiş ve gelişmemiş olgularda delta antikoru (Anti-HDV) sıklığının belirlenmesi ve klinik etkilerinin irdelenmesi amaçlandı.

\section{GEREÇ VE YÖNTEMLER}

Bu kesitsel çalışmaya Şubat 2017-Şubat 2018 tarihleri arasında Siirt Devlet Hastanesi Enfeksiyon Hastalıkları polikliniğine başvuran Anti-HDV testi bakılmış tüm olgular (toplam 462 olgu) dahil edilmiştir. Avrupa karaciğer araştırmaları derneği (EASL)'nin 2017 Klinik Uygulama Yönergesi'ne (10) göre olgularımızın \%62,3'ü $(\mathrm{n}=288) \mathrm{HBV}$ ile kronik olarak enfekte, \%37,7'si ( $\mathrm{n}=174)$ ise KHB gelişmiş olgulardan oluşmaktaydı.

Epidemiyolojik verilere ve HBV deoksiribonükleik asit (DNA), hepatit B "e" antijeni (HBeAg), alanin aminotransferaz (ALT), HDV ribonükleik asit (RNA) sonuçları ile siroz ve HCC durumu ile ilgili verilere retrospektif olarak ulaşılmıştır. ALT düzeyinin en az 2 ölçümde normal sınırın 2 katı ve üzerinde olduğu olgular "ALT düzeyi yüksek olgular" olarak kabul edilmiştir. Çalışmaya alınan hastalar Anti-HDV pozitif $(n=126)$ ve negatif $(n=334)$ olmak üzere iki gruba ayrıldı. KHB, siroz ve HCC sıklığı gruplar arasında karşılaştırıldı. HCV ile enfekte olgular çalışmaya dahil edilmemiştir.

Anti-HDV, hepatit B yüzey antijeni (HBsAg) ve $\mathrm{HBeAg}$ tespiti için yarışmalı (kompetitif) immünoanaliz (ELISA) kiti (DIA.PRO, Milano, Italy) kullanılmıştır. Serum HBV DNA ve HDV RNA düzeyleri gerçek zamanlı polimeraz zincir reaksiyonu (RT-PCR) metodu kullanılarak üretici firmanın (QIAGEN Inc, Hilden, Almanya) önerileri doğrultusunda çalışılmıştır.

$\mathrm{Bu}$ çalışma Siirt Üniversitesi Etik kurulu tarafindan onaylanmıştır (Karar tarihi: 07/05/2018, sayı: 09).

\section{İstatistiksel Analiz}

İstatistiksel analizler SPSS versiyon 21 yazılımı kullanılarak yapıldı. Değişkenlerin normal dağılıma uygunluğu görsel (histogram) ve analitik yöntemlerle (Shapiro-Wilk testi) incelendi. Yaş değişkeni gruplar arasında Mann-Whitney $U$ testi kullanılarak karşılaştırıldı. Gruplar arasında cinsiyet, KHB, siroz, HCC, artmış ALT düzeyi ve HBeAg pozitifliği sıklıkları bakımından fark bulunup bulunmadığı yerine göre $\mathrm{Ki}$ kare ya da Fisher exact testleri kullanılarak karşılaştırıldı. P-değerinin 0,05'in altında olduğu durumlar istatistiksel olarak anlamlı sonuçlar olarak değerlendirildi.

\section{BULGULAR}

Toplam 462 olgunun 205'i $(\% 44,4)$ kadın, 257'si erkek $(\% 55,6)$ olup, medyan yaşı 37 (çeyrekler arası aralık (IQR) 26 ila 49) idi. Hastaların 128'inde (\%27,8) AntiHDV pozitifliği saptanmıştır. Tüm olguların $\% 3,5$ 'inde siroz, \%0,6'sında ise HCC mevcut idi. Çalışmamızda nonsirotik olgulardaki Anti-HDV sıklığı \%26,2 iken, sirotik olgularda bu oran \%68,8 idi. Delta antikoru pozitifliği oranının kırsal kesimden gelen olgularda, kentsel kesimden gelen olgulara göre anlamlı oranda daha yüksek olduğu görülmüştür (sırasıyla \%37,6 ve \%24, $\mathrm{p}=0,003)$.

Çalışmamızda anti delta pozitif olguların sadece \%25'inde (32/128) HDV RNA bakılabilmiş ve bu olgularında sadece \%28,1'inde (9/32) HDV RNA pozitifliği saptanabilmiştir. Anti-HDV pozitif olguların HBV DNA düzeyi olguların \%30,5'inde negatif, \%40,6'sında düşük düzeylerde pozitif, olguların önemli bir bölümünde ise $(\% 28,9)$ yüksek düzeyde pozitif olarak saptanmıştır. 
Anti-HDV pozitif ve negatif hasta grupları kıyaslandığında gruplar arasında yaş ve cinsiyet açısından anlamlı fark gözlenmez iken $(p=0,224, p=0,966)$, antiHDV pozitif olgulardaki KHB, siroz ve HCC siklığının anti-HDV negatif olgulara göre anlamlı oranda yüksek olduğu görülmüştür ( $p=0,003, p=0,001, p=0,021)$ (Tablo 1). Buna ek olarak anti-HDV pozitif olgularda ALT yüksekliği sıklığı negatif olgulara göre anlamlı oranda daha yüksekti $(p=0,001)$. HBeAg sıklığının anti-HDV pozitif olgularda negatif olgulara göre anlamlı oranda daha düşük olduğu görülmüştür $(\mathrm{p}=0,005)$ (Tablo 1).

Tablo 1. Anti-HDV pozitif ve negatif grupların demografik özelliklerinin ve laboratuar bulgularının karşılaştırılması

\begin{tabular}{|l|c|c|c|}
\hline Özellik & $\begin{array}{c}\text { Anti-HDV } \\
\text { pozitif } \\
\text { olgular } \\
\text { (n=128) }\end{array}$ & $\begin{array}{c}\text { Anti-HDV } \\
\text { negatif } \\
\text { olgular } \\
\text { (n=334) }\end{array}$ & p değeri \\
\hline $\begin{array}{l}\text { Yaş, medyan } \\
\text { (IQR) }\end{array}$ & $37(26)$ & $37(21)$ & 0,224 \\
\hline Cinsiyet, n (\%) & $71(55,5)$ & $186(55,7)$ & 0,966 \\
\hline \multicolumn{1}{|c|}{ Erkek } & $57(44,5)$ & $148(44,3)$ & \\
\hline $\begin{array}{l}\text { Kronik hepatit } \\
\text { sıklı̆̆ı, n (\%) }\end{array}$ & $62(48,4)$ & $112(33,5)$ & $* 0,003$ \\
\hline $\begin{array}{l}\text { Siroz sıklığı, n } \\
\text { (\%) }\end{array}$ & $11(8,6)$ & $5(1,5)$ & $* 0,001$ \\
\hline $\begin{array}{l}\text { HCC sıklığı, n } \\
\text { (\%) }\end{array}$ & $3(2,3)$ & $0(0)$ & $* 0,021$ \\
\hline $\begin{array}{l}\text { ALT düzeyi } \\
\text { yüksek olgu } \\
\text { sıklığı, n (\%) }\end{array}$ & $40(31,2)$ & $56(16,8)$ & $* 0,001$ \\
\hline $\begin{array}{l}\text { HBeAg pozitifliği } \\
\text { sıklığı, n (\%) }\end{array}$ & $27(21,1)$ & $37(11,1)$ & $* 0,005$ \\
\hline
\end{tabular}

*Istatistiksel olarak anlamlı $(\mathrm{p}<0,05)$; Anti-HDV: hepatit delta virus antikoru; IQR: çeyrekler arası aralık, (25. ve 75. persentil değerleri arasındaki fark); HCC: hepatosellüler karsinom; ALT: alanin aminotransferaz; HBeAg: hepatit B "e" antijeni.

\section{TARTIŞMA VE SONUÇ}

Siirt ilindeki HBsAg pozitif olgularda anti-HDV seropozitifliği oranının araştırıldığ 1 bu retrospektif kesitsel çalışmada anti delta pozitifliğinin klinik seyre etkisi de değerlendirildi. Anti-HDV testi çalışılmış olan HBsAg pozitif olgularda delta antikoru pozitifliği oranının \%27,7 olduğu ve anti-HDV pozitif olgularda negatif olgulara oranla karaciğer hastalığı seyrinin daha ağır (artmış ALT düzeyi, artmış siroz ve HCC sıklığı) olduğu görülmüştür.

Sunulan çalışmada Siirt ilindeki bu yüksek oran $(\% 27,7)$ hem Güneydoğu Anadolu Bölgesi ortalamasının (\%4,5) hem de Siirt'e komşu iller olan Diyarbakır $(\% 8,5)$ ve Van'dan $(\% 15,2)$ bildirilmiş oranların çok üzerindedir $(8,11,12)$. Bu sonuçta ilimizdeki HBsAg seropozitifliği oranının (\%10) bu iki ile (Van'da \%2,9, Diyarbakır'da $\% 4,93)$ kıyasla daha yüksek oluşu etkili olmuş olabilir (12-14). Ancak HDV enfeksiyonu epidemiyolojisi çoğunlukla HBV prevalansını yansıtıyor olsa da coğrafi bölgeler arasında farklılıklar olabileceği ve bu varsayımın aksi durumlarla da karşılaşılabileceği düşünüldüğünde çalışmamızdaki bu yüksek oranın sadece HBV prevalansındaki yüksekliğe atfedilmesi gerçekçi olmayacaktır $(2,15)$.
Çalışmamızda delta antikoru pozitifliği oranının kırsal kesimde, kentsel kesime göre anlamlı oranda yüksek olduğu görülmüştür (sırasıyla \%37,6 ve \%24, p=0,003). $\mathrm{Bu}$ durumun bölgemizdeki kırsal kesimde kültürel olarak kalabalık aile yapısının yaygın olmasının veya dağlık arazi yapısından kaynaklanan ulaşım zorluğu nedeniyle HBV aşılama ve aile tarama programlarının yaygınlaştırılmasındaki güçlüklerin bir sonucu olabileceği düşünüldü.

Ülkemizde HBV aşısı 20 yıldan uzun zamandır ulusal aşılama programında yer almakta ve tüm yenidoğanlara rutin olarak uygulanmaktadır (16). Dünya genelinde olduğu gibi HBV aşılamasının ülkemizde yaygınlaşması sonrasında anti-delta prevalansında anlamlı oranda düşüş elde edilirken, ilimizde bu oranlarının halen yüksek olması oldukça çarpıcıdır $(9,11,17)$. Çalışmamızın bir diğer çarpıcı sonucu ise anti-HDV pozitif olguların \%7,8'inin 18-20 yaş aralığında olması ve bizim çalışmamızdaki anti-HDV pozitif olguların büyük çoğunluğunda yaş aralığı 21-40 yaş iken bu oranın batı illerinde 50-59 yaş olarak bildirilmiş olmasıdır (18). Bu sonuç ilimizdeki HBsAg pozitif olgularda HDV'nin rutin olarak taranmasının, aile tarama programlarının ve riskli grupları hedefleyen ulusal HBV aşılama kampanyalarının yaygınlaştırılmasının gerekliliğini göstermektedir.

Anti-HDV, aktif HDV enfeksiyonundan ziyade HDV ile maruziyetin bir delili olup viral eradikasyon sonrasında da sebat edebilmektedir. Bu nedenle HDV'nin gerçek prevalansinın belirlenmesinde HDV RNA tetkikinin daha değerli olduğu kabul edilmektedir $(19,20)$. Bununla birlikte çalışmamızda anti delta pozitif olguların sadece $\% 25$ 'inde HDV RNA bakılabilmiş ve bu olguların da sadece \%28,1'inde HDV RNA pozitifliği saptanabilmiştir. Ülkemizin farklı illerinden yapılan çalışmalarda $(18,21)$ anti-HDV pozitif olgularda HDV RNA pozitifliği oranları \%60'lara ulaşırken bizim çalışmamızda bu oranın düşük olması HDV RNA testi yapılabilen olgu sayımızın az olması ile ilişkili olabileceği gibi, serum HDV RNA düzeyindeki dalgalanmalar ve HDV RNA tespitinde yaşanan standardizasyon sorunlarına bağlı görülebilecek yalancı negatiflik ile de açıklanabilir (22).

Önceki literatür verilerini destekler şekilde sunulan çalışmada da HDV koenfeksiyonu varlığında ALT yüksekliği ve hepatit B' de kronikleşme oranları ile siroz ve HCC sıklığının HBV mono enfeksiyonuna göre anlamlı oranda yüksek olduğu görülmüştür (23). Benzer şekilde çalışmamızdaki sirotik olgularda nonsirotik olgulara göre HDV sıklığının anlamlı oranda daha yüksek oluşu ve HCC gelişmiş tüm olguların koenfekte olgulardan oluşması da HDV koenfeksiyonu varlığının daha ağır karaciğer hastalığı ile ilişkili olduğunu doğrulamaktadır (24). HDV ile koenfekte olguların erken tespiti ve tedavisi ile bu komplikasyonların gelişimi önlenebilir $(8,11)$. Bu nedenle $\mathrm{HBsAg}$ pozitif yüksek riskli olguların ve aile bireylerinin taranarak enfekte olguların erken tespitinin ve tedavisinin sağlanması, bölgedeki HDV ilişkili mortalite ve morbiditenin azaltılmasında fayda sağlayacaktır.

HDV ile koenfekte olguların çoğunda HDV'nin baskın rol oynayarak HBV replikasyonunu baskıladığı ettiği görülmektedir (25). Bunun doğal bir sonucu olarak HDV ile koenfekte olgularda çoğunlukla HBeAg'nin negatif 
olduğu ve HBV DNA düzeyinin de negatif veya düşük düzeylerde olduğu rapor edilmiştir $(8,26,27)$. Bizim çalışmamızda da benzer şekilde HDV ile koenfekte olguların büyük çoğunluğunda $\mathrm{HBeAg}$ negatif, $\mathrm{HBV}$ DNA düzeyi ise negatif veya düşük düzeylerde saptanmıştır. Öte yandan son yıllarda yapılan çalışmalarda HDV ve HBV virüsleri arasındaki etkileşimin çok daha karmaşık ve dinamik bir süreç olduğu ve bu süreç içerisinde her iki virüse ait serum viral yük düzeyinde de dalgalanmalar görülebileceği ortaya konmuştur $(28,29)$. Bizim çalışmamızda da bunu doğrular şekilde olgularımızın önemli bir bölümünde $(\% 28,9)$ yüksek HBV DNA düzeyleri saptanmıştır. Bu sonuç delta koenfeksiyonunda gelişen karaciğer hasarı üzerinde HBV'nin de en az HDV kadar etkisi olabileceğini düşündürmektedir. $\mathrm{Bu}$ nedenle olguların HBV DNA viral yüklerinin de titizlikle takibi ve gereğinde oral antiviral tedavi ile viral yükün baskılanması önemli klinik fayda sağlayabilir.

Çalışmamızın en önemli kısıtlılığı retrospektif bir çalışma olması nedeniyle risk faktörlerinin belirlenememiş olması, ve koenfeksiyon ile süperenfeksiyon ayrımının yapılamamış olmasıdır. Bir diğer kısıtlılı̆̆ pozitif tüm olgulara HDV RNA bakılamamış olduğundan aktif HDV enfeksiyonu oranının belirlenememiş olmasıdır.

$\mathrm{Bu}$ çalışmada elde edilen verilere dayanarak, Siirt ilinde HBV ile enfekte olgularda anti-HDV sıklığının (\%27,7) halen Türkiye ortalamasının $(\% 5,2)$ çok üzerinde olduğu ve anti-HDV pozitif olguların KHB, siroz ve HCC gelişimi açısından anti-HDV negatif olgulara oranla daha yakın izlem gerektirdiği söylenebilir. İlimizdeki durumun ciddiyeti düşünüldüğünde bölgedeki hekimlerin HDV konusundaki farkındalığının arttırılması ile enfekte olguların erken tespitinin yanında korunma ile ilgili çabanın arttırılarak aile tarama programlarının ve riskli grupları hedefleyen ulusal HBV aşılama kampanyalarının yaygınlaştırılması açık bir gerekliliktir.

Yazarların Katkıları: Fikir/Kavram: T.B.; Tasarım: T.B.; Veri Toplama ve/veya İşleme: T.B.; Analiz ve/veya Yorum: T.B.; Literatür Taraması: T.B.; Makale Yazımı: T.B.

\section{KAYNAKLAR}

1. Lin JH, Chang MF, Baker SC, Govindarajan S, Lai MM. Characterization of hepatitis delta antigen: specific binding to hepatitis delta virus RNA. J Virol. 1990; 64(9): 4051-8.

2. Chen HY, Shen DT, Ji DZ, Han PC, Zhang WM, Ma $\mathrm{JF}$, et al. Prevalence and burden of hepatitis D virus infection in the global population: a systematic review and meta-analysis. Gut. 2019; 68(3): 512-21.

3. Shen DT, Ji DZ, Chen HY, Goyal H, Pan S, Xu HG. Hepatitis D: not a rare disease anymore: global uptodate for 2017-2018. Gut. 2020; 69(4): 786-8.

4. Yurdaydin C, Toy M. Hepatitis delta virus infection: a large burden after all ? J Infect Dis. 2020; 221(10): 1573-5.

5. Miao Z, Zhang S, Ou X, Li S, Ma Z, Wang W, et al. Estimating the global prevalence, disease progression, and clinical outcome of hepatitis delta virus infection. J Infect Dis. 2020; 221(10): 1677-87.
6. Wedemeyer H, Negro F. Devil hepatitis D: an orphan disease or largely underdiagnosed? Gut. 2019; 68(3): 381-2.

7. Mhalla S, Kadri Y, Alibi S, Letaief A, Boukadida J, Hannachi N. Hepatitis D virus infection among hepatitis B surface antigen carriers and in "isolated anti-HBc" antibodies profile in central Tunisia. Hepat Mon. 2016; 16(1): e32354.

8. Dulger AC, Suvak B, Gonullu H, Gonullu E, Gultepe B, Aydin I, et al. High prevalence of chronic hepatitis $\mathrm{D}$ virus infection in Eastern Turkey: urbanization of the disease. Arch Med Sci. 2016; 12(2): 415-20.

9. Değertekin H, Yalçin K, Yakut M. The prevalence of hepatitis delta virus infection in acute and chronic liver diseases in Turkey: an analysis of clinical studies. Turk J Gastroenterol. 2006; 17(1): 25-34.

10. European Association for the Study of the Liver. EASL 2017 Clinical Practice Guidelines on the management of hepatitis B virus infection. J Hepatol. 2017; 67(2): 370-98.

11. Ayaz C, Tekin Koruk S, Yalci A, Yamazhan T, Aygen B, Tosun S, et al. Epidemiology and risk factors of hepatitis delta infection in Turkey. J Pure Appl Microbio. 2013; 7(4): 2809-13.

12. Celen MK, Ayaz C, Hosoglu S, Geyik MF, Ulug. M. Anti-hepatitis delta virus seroprevalence and risk factors in patients with hepatitis B in Southeast Turkey. Saudi Med. J. 2006; 27(5): 617-20.

13. Tunç N, Eraydın H, Çetinkaya E, Oduncu MK, Toy Ş. Siirt Devlet Hastanesi'ne başvuran hastalarda HBsAg, Anti-HBs, Anti-HCV ve Anti-HIV seroprevalansı. Viral Hepatit Derg. 2011; 17(1): 7-11.

14. Arabacı F, Şahin HA, Şahin İ, Kartal Ş. Kan donörlerinde HBV, HCV, HIV ve VDRL seropozitifliği. Klimik Derg. 2003; 16(1): 18-20.

15. Parlak E, Ertürk A, Parlak M, Koşan Z, Albayrak A, Özkurt Z, et al. Assessment of patients with hepatitis D. Viral Hepatitis Journal. 2015; 21(3): 80-4.

16. Ayaz C, Yardımcı C, Çandır N, Ersöz G, Şanlıdağ T, Tiğlı A, ve ark. Kronik hepatit D virusu infeksiyonunun yönetimi: Türk Klinik Mikrobiyoloji ve İnfeksiyon Hastalıkları Derneği Viral Hepatit Çalışma Grubu Uzlaşı Raporu. Klimik Derg. 2014; 27(1): 40-7.

17. Parlak E, Ertürk A, Parlak M, Koşan Z, Albayrak A, Öztürk Z, et al. Assessment of patients with hepatitis D. Viral Hepat J. 2015; 21(3): 80-4.

18. Yolcu A, Karabulut N, Alaçam S, Önel M, Büyük M, Güllüoğlu M, et al. Frequency of hepatitis delta virus in hepatitis B surface-antigen-positive patients. Viral Hepat J. 2019; 25(1): 14-8.

19. Negro F, Bergmann KF, Baroudy BM, Satterfield WC, Popper H, Purcell RH, et al. Chronic hepatitis D virus (HDV) infection in hepatitis $B$ virus carrier chimpanzees experimentally superinfected with HDV. J Infect Dis. 1988; 158(1): 151-9.

20. Borghesio E, Rosina F, Smedile A, Lagget M, Niro MG, Marinucci G, et al. Serum immunglobulin M antibody to hepatitis $\mathrm{D}$ as a surrogate marker of hepatitis D in interferon-treated patients and in patients who underwent liver transplantation. Hepatology. 1998; 27(3): 873-6. 
21. Bahcecioglu IH, Aygun C, Gozel N, Poyrazoğlu OK, Bulut Y, Yalniz M. Prevalence of hepatitis delta virus (HDV) infection in chronic hepatitis $\mathrm{B}$ patients in eastern Turkey: still a serious problem to consider. J Viral Hepat. 2011; 18(7): 518-24.

22. Noureddin M, Gish R. Hepatitis Delta: Epidemiyoloji, diagnosis and management 36 years after discovery. Curr Gastroenterol Rep. 2014; 16(1): 365.

23. Fattovich G. Natural history and prognosis of chronic hepatitis B. Semin Liver Dis. 2003; 23(1): 47-58.

24. Amini N, Alavian SM, Kabir A, Saiedi Hosseini SY, Aalaei Andabili SH. Clinical features and seroepidemiology of anti-HDV Antibody in patients with chronic hepatitis B virus infection in Iran: a meta-analysis. Hepat Mon. 2011; 11(12): 960-7.

25. Aberra H, Gordien E, Desalegn H, Berhe N, Medhin $\mathrm{G}$, Mekasha B, et al. Hepatitis delta virus infection in a large cohort of chronic hepatitis B patients in Ethiopia. Liver Int. 2018; 38(6): 1000-9.

26. Fouad R, Abdo M, Eldeen HG, Sabry D, Atef M, Ahmed R, et al. Influence of delta virus infection on the virologic status in Egyptian patients with chronic hepatitis B virus genotype D. J Med Virol. 2016; 88(5): 837-42.

27. Ghamari S, Alavian SM, Rizzetto M, Olivera A, Smedile A, Khedive A, et al. Prevalence of hepatitis delta virus (HDV) infection in chronic hepatitis B patients with unusual clinical pictures. Hepat Mon. 2013; 13(38): e6731.

28. Schaper M, Rodriguez-Frias F, Jardi R, Tabernero D, Homs M, Ruiz G, et al. Quantitative longitudinal evaluations of hepatitis delta virus RNA and hepatitis $\mathrm{B}$ virus DNA shows a dynamic, complex replicative profile in chronic hepatitis B and D. J Hepatol. 2010; 52(5): 658-64.

29. Wedemeyer H. Re-emerging interest in hepatitis delta: new insights into the dynamic interplay between HBV and HDV. J Hepatol. 2010; 52(5): 6279. 